\title{
PEDF protects human retinal pigment epithelial cells against oxidative stress via upregulation of UCP2 expression
}

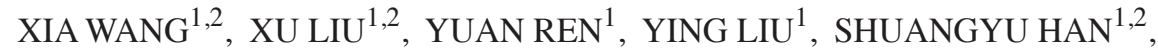 \\ JINGKANG ZHAO $^{1,2}$, XINGCHUN GOU ${ }^{2}$ and YUAN HE ${ }^{1}$

\begin{abstract}
${ }^{1}$ Department of Ophthalmology, The Second Affiliated Hospital of Xi'an Medical University, Ocular Immunology and Inflammation Institute, Shaanxi Provincial Clinical Research Center for Ophthalmology, Xi'an, Shaanxi 710038;

${ }^{2}$ Department of Neurobiology, The Shaanxi Key Laboratory of Brain Disorders, Xi'an Medical University,
\end{abstract} \\ Xi'an, Shaanxi 710021, P.R. China
}

Received January 1, 2018; Accepted September 7, 2018

DOI: $10.3892 / \mathrm{mmr} .2018 .9645$

\begin{abstract}
To investigate the protective function of pigment epithelium-derived factor (PEDF) against oxidative stress (OS) in ARPE-19 cells, ARPE-19 cells were divided into different OS groups and treated with various concentrations of $\mathrm{H}_{2} \mathrm{O}_{2}(0$, $75,150$ and $200 \mu \mathrm{mol} / \mathrm{l})$ for $24 \mathrm{~h}$. To establish the protective group, $200 \mathrm{ng} / \mathrm{ml}$ of PEDF was administered to ARPE-19 cells. Cell Counting Kit- 8 assays and cell growth curve experiments were performed to determine levels of cell viability; lactate dehydrogenase and propidium iodide (PI) staining assays were also performed. The expression levels of genes associated with apoptosis as well as uncoupling protein 2 (UCP2) were detected by reverse transcription-quantitative, or semi-quantitative polymerase chain reaction. Furthermore, an OS injury animal model was established in both C57BL/6 and BALB/c mice via injection of $5 \mu \mathrm{g}$ of PEDF in the vitreous cavity and subsequent injection of $150 \mu \mathrm{M} \mathrm{H}_{2} \mathrm{O}_{2}$ following a $24 \mathrm{~h}$ time interval. Hematoxylin and eosin (H\&E) staining, as well as UCP2 immunofluorescent labeling were also performed. One-way analysis of variance was used to determine statistically significant differences, followed by multiple comparison analysis using the Newman Keuls method. The results of cell viability assays demonstrated that the numbers of apoptotic cells were increased following treatment with $\mathrm{H}_{2} \mathrm{O}_{2}$ in a dose-dependent
\end{abstract}

Correspondence to: Professor Yuan He, Department of Ophthalmology, The Second Affiliated Hospital of Xi'an Medical University, Ocular Immunology and Inflammation Institute, Shaanxi Provincial Clinical Research Center for Ophthalmology, 167 Fang Dong Street, Xi'an, Shaanxi 710038, P.R. China

E-mail: openji7127@hotmail.com

Professor Xingchun Gou, Department of Neurobiology, The Shaanxi Key Laboratory of Brain Disorders, Xi'an Medical University, 1 Xin Wang Road, Wei Yang, Xi'an, Shaanxi 710021, P.R. China

E-mail: gouxingchun@189.cn

Key words: pigment epithelium-derived factor, uncoupling protein 2, oxidative stress, ARPE-19 cells manner; however, this effect was reversed following treatment with PEDF. The expression levels of caspase 3 and B cell lymphoma $(\mathrm{Bcl} 2)$ associated $\mathrm{X}$ genes associated with apoptosis were inhibited, whereas levels of the anti-apoptotic gene $\mathrm{Bcl} 2$ were enhanced following treatment with PEDF in different passages of ARPE-19 cells. Significant differences were demonstrated in the levels of UCP2 gene expression between the $\mathrm{PEDF}+\mathrm{H}_{2} \mathrm{O}_{2}$ treated group and cells treated with $\mathrm{H}_{2} \mathrm{O}_{2}$ alone. Labeling of the UCP2 detector in the confocal images demonstrated decreased UCP2 protein staining in the retinal pigment epithelium (RPE) cells and RPE layers following $\mathrm{H}_{2} \mathrm{O}_{2}$ injury; however, this effect was inhibited following treatment with PEDF. H\&E staining was performed to investigate the thickness of the RPE layers, and the results revealed that thicknesses were significantly increased in sections treated with PEDF during OS, due to increased numbers of RPE cells. Furthermore, PEDF was demonstrated to increase UCP2 gene expression in ARPE-19 cells and animal RPE layers under OS, which suggested that PEDF may protect RPE cells and tissues during oxidative injury.

\section{Introduction}

In recent years, it has been well established that age-associated macular degeneration (AMD) represents a leading cause of blindness in the elderly population (1). Numerous clinical and experimental studies investigating the treatment of AMD have been performed, including the administration of drugs, surgery and laser treatment (2). Furthermore, it has been suggested that the retinal pigment epithelium (RPE) layer may be the initial tissue type to be affected during AMD. A previous study demonstrated that the accumulation of oxidative damage may result in decreased function of RPE cells in patients with AMD (3). An increasing number of studies have supported the important role of oxidative stress (OS) during the development of age-associated cell dysfunction (4), leading to the development of AMD (5). Cellular or molecular damage caused by reactive oxygen species (ROS) has been suggested to represent the causative factors of OS (6) by inducing RPE cell death, subsequent atrophy of the photoreceptors and loss of vision (7). Therefore, a novel therapeutic strategy resulting 
in the rescue of RPE cells may prevent the occurrence or progression of AMD.

Increasing evidence has supported the hypothesis that OS-induced mitochondrial damage can lead to the disruption of mitochondrial energy metabolism, and promote the occurrence and development of $\operatorname{AMD}(8,9)$. Mitochondrial enzymes are the predominant source of ROS-producing enzymes in cells $(10,11)$. As inner mitochondrial membrane proteins, mitochondrial uncoupling proteins (UCPs) regulate ROS (12-16). It has been well established that UCPs are the major antioxidants associated with the reduction of OS and the prevention of oxidative damage via regulation of ROS homeostasis (17). A number of studies have demonstrated that among the family of UCPs, UCP2 is an important factor associated with the prevention of OS (18-20). UCP2 has also been revealed to suppress the generation of ROS due to its function as a cationic carrier protein on the mitochondrial intima (20).

Furthermore, numerous studies have demonstrated that decreased levels of pigment epithelium-derived factor (PEDF) are associated with AMD (21-23). PEDF is a $50 \mathrm{kDa}$ glycoprotein belonging to the serine protease inhibitor superfamily, that is secreted by RPE cells and was first identified in cultured fetal human RPE cells (24). RPE is an ocular tissue that expresses high levels of PEDF and breaks down the protein product into photoreceptor matrices (25-27). In addition, PEDF may enhance the survival of photoreceptors and retinal neurons $(27,28)$. Our previous study demonstrated that PEDF protects RPE cells against OS-induced aging (29). Therefore, we hypothesized that PEDF may protect RPE cells and tissues via regulation of UCP2 expression during $\mathrm{H}_{2} \mathrm{O}_{2}$ injury.

The aim of the present study was to investigate the effects of PEDF on cell viability, UCP2 gene expression and RPE tissues during OS in vitro and in vivo, as well as to determine the potential role of PEDF in this protective mechanism.

\section{Materials and methods}

Materials. Human ARPE-19 cells were obtained from the American Type Culture Collection (Manassas, VA, USA). Dulbecco's modified essential medium (DMEM) and fetal bovine serum (FBS) were obtained from Gibco (Thermo Fisher Scientific, Inc., Waltham, MA, USA). Trypsin digestion solution $(0.25 \%$ trypsin and $0.02 \%$ ethylenediaminetetraacetic acid), $30 \% \mathrm{H}_{2} \mathrm{O}_{2}, 100 \mathrm{X}$ penicillin $(100 \mathrm{u} / \mathrm{ml}) /$ streptomycin (0.1 mg/ml), PBS, Cell Counting Kit-8 (CCK-8), lactate dehydrogenase (LDH) kit, propidium iodide (PI) were all purchased from (Thermo Fisher Scientific, Inc.), and UCP2 antibodies (cat. no. ab77363; $100 \mu \mathrm{g}$ ) were all purchased from Abcam (Cambridge, UK). PEDF (purity $>98 \%$ ) was purchased from PeproTech, Inc. (Rocky Hill, NJ, USA). PEDF was dissolved in $1 \mathrm{X}$ PBS supplement to a fixed concentration of $20 \mu \mathrm{g} / \mathrm{ml}$ and subsequently diluted to a concentration of $200 \mathrm{ng} / \mathrm{ml}$ in culture media prior to use.

Animals. Male C57BL/6 mice and BALB/c mice (1-week-old; $\sim 30 \mathrm{~g})$ were purchased from Xi'an Jiao Tong University Medicine Laboratory Animal Center (Xi'an, China). The total number of each type of mice used was 40 . The temperature was at $20-25^{\circ} \mathrm{C}$. The relative humidity, air velocity and air pressure were $40-70,0.1-0.2 \mathrm{~m} / \mathrm{sec}$ and $(20-50)^{2} \mathrm{~Pa}$. The light/dark cycle of housing conditions was 12-h. Animals were fed ad libitum with standard laboratory food and water, and permitted to acclimatize for $\geq 1$ week prior to further experimentation. Mice were randomly separated into a control group and various treatment groups. The number of mice in each treatment group and control group was 10. All animal experiments were approved by the Xi'an Jiao Tong University Animal Research Committee (Xi'an, China).

Cell culture. ARPE-19 cell passages used in the present study ranged from 5-30 generations. Cells were inoculated into $25-\mathrm{cm}^{2}$ plastic culture flasks at a density of $1.0-3.0 \times 10^{5} / \mathrm{cm}^{2}$, subsequently cultured at $37^{\circ} \mathrm{C}$ in DMEM supplemented with FBS $(100 \mathrm{ml} / \mathrm{l})$ and penicillin/streptomycin $(100 \mathrm{U} / \mathrm{ml})$, and then incubated in a humidified atmosphere of $5 \% \mathrm{CO}_{2}$ at $37^{\circ} \mathrm{C}$ for $48-72 \mathrm{~h}$. Cells were observed under a phase contrast microscope at $10 \mathrm{X}$ and $40 \mathrm{X}$ for three days. Following this, oxidative damage models using ARPE-19 cells were established in vitro according to a previously published protocol (29-31).

Cell viability assay. ARPE-19 cells were seeded in E plate $\left(5 \times 10^{3} /\right.$ well) and placed in an xCell-igence RTCA DP instrument (ACEA Biosciences, Inc., San Diego, CA, USA) in order to determine cell growth curves. Once the cell index reached 4-5, oxidative groups were treated with $\mathrm{H}_{2} \mathrm{O}_{2}(0,75,150$, and $200 \mu \mathrm{M})$ for $24 \mathrm{~h}$. In addition, the protected cell group, cells were treated with $200 \mathrm{ng} / \mathrm{ml}$ of PEDF or $\mathrm{H}_{2} \mathrm{O}_{2}(0,75,150$, and $200 \mu \mathrm{M}$ ) for $24 \mathrm{~h}$ in humidified atmosphere of $5 \% \mathrm{CO}_{2}$ at $37^{\circ} \mathrm{C}$. The cells of the $\mathrm{H}_{2} \mathrm{O}_{2}$-only and PEDF-treated groups were then removed from the instrument and the cell growth curves were analyzed.

CCK-8 assay. ARPE-19 cell suspension (100 $\mu \mathrm{l})$ was seeded in 96-well plates and then incubated in humidified atmosphere of $5 \% \mathrm{CO}_{2}$ at $37^{\circ} \mathrm{C}$ for $24 \mathrm{~h}$. Different concentrations of $\mathrm{H}_{2} \mathrm{O}_{2}$ $(0,75,150$, and $200 \mu \mathrm{M})$ were added to the wells, as well as PEDF (200 ng/ml) for the PEDF-treated group. Plates were then incubated for $24 \mathrm{~h}$. CCK-8 solution $(10 \mu \mathrm{l})$ was then added to each well and the absorbance at $450 \mathrm{~nm}$ was measured at $0.5,1,2,3$ and $4 \mathrm{~h}$ time intervals using a microplate reader. The following equation was used to determine cell viability: Cell proliferation $(\%)=[($ dosing $)-($ blank $)] /[(0$ dosing $)-($ blank $)]$ $\mathrm{x} 100$.

LDH assay. $\mathrm{LDH}$ reaction mixture in the LDH Assay kit was incubated with ARPE-19 cells in 96-well plates in humidified atmosphere of $5 \% \mathrm{CO}_{2}$ at $37^{\circ} \mathrm{C}$ for $30 \mathrm{~min}$. The suspension cell density applied was $4 \times 10^{4} / \mathrm{ml}$. Following this, the reaction was terminated and the absorbance was measured at $490 \mathrm{~nm}$ using a Benchmark microplate reader (Bio-Rad Laboratories, Inc., Hercules, CA, USA). Cell mortality rates were then determined for the different cell groups.

PI staining. The cells were centrifuged $(300 \mathrm{x}$ g, at room temperature for $5 \mathrm{~min}$ ) and collected, the supernatant was discarded, and the cells were washed twice with pre-cooled 
Table I. Primer sequences of genes investigated by reverse transcription-semi-quantitative polymerase chain reaction and reverse transcription-quantitative polymerase chain reaction.

\begin{tabular}{lll}
\hline Gene name & \multicolumn{1}{c}{ Forward 5'-3' } & \multicolumn{1}{c}{ Reverse 5'-3' } \\
\hline UCP2 & CTACAAGACCATTGCACGAGAGG & AGCTGCTCATAGGTGACAAACAT \\
Caspase3 & TGGAACAAATGGACCTGTTGACC & AGGACTCAAATTCTGTTGCCACC \\
Bax & CCTTTTCTACTTTGCCAGCAAAC & GAGGCCGTCCCAACCAC \\
Bcl2 & ATGTGTGTGGAGAGCGTCAACC & TGAGCAGAGTCTTCAGAGACAGCC \\
GAPDH & CAAGGTCATCCATGACAACTTTG & GTCCACCACCCTGTTGCTGTAG \\
\hline
\end{tabular}

Bcl2, B cell lymphoma 2; Bax, Bcl2 associated X; UCP2, uncoupling protein 2.

PBS. $70 \%$ ethanol was added and cells were fixed at $4^{\circ} \mathrm{C}$ overnight. The cells were centrifuged ( $300 \mathrm{x}$ g, at room temperature for $5 \mathrm{~min}$ ), washed once with $1 \mathrm{ml}$ of PBS and incubated with $4 \mu \mathrm{g} / \mathrm{ml}$ of PI solution to stain the nuclei of dead cells for $30 \mathrm{~min}$ at $4^{\circ} \mathrm{C}$ in the dark. Numbers of stained cells were estimated via fluorescence microscopy (DM2000LED/DF450C; Leica, Microsystems $\mathrm{GmbH}$, Wetzlar, Germany) at $\mathrm{x} 4$ magnification $(n=6)$.

RNA extraction and reverse transcription-semi-quantitative polymerase chain reaction ( $R T-P C R)$. Total RNA was isolated from the cells using TRIzol reagent (Thermo Fisher Scientific, Inc.) in ARPE-19 cells. RNA yield was determined spectrophotometrically (A260/A280). A First Strand cDNA Synthesis kit (Thermo Fisher Scientific, Inc.) was used to perform RT, and $2 \mu \mathrm{g}$ of RNA was incubated with $1 \mu \mathrm{l}$ of oligo (dT) primer, $7 \mu \mathrm{l}$ of RNase-free $\mathrm{dH}_{2} \mathrm{O}, 4 \mu \mathrm{l}$ of $5 \mathrm{X}$ reaction buffer, $1 \mu \mathrm{l}$ of RiboLock Rnase inhibitor, $2 \mu \mathrm{l}$ of $10 \mathrm{mM}$ dNTP mix, $1 \mu \mathrm{l}$ RevertAid RT and RNase-free $\mathrm{dH}_{2} \mathrm{O}$, the final volume of which was $20 \mu \mathrm{l}$. The reaction mixture was incubated at $70^{\circ} \mathrm{C}$ for $5 \mathrm{~min}$, followed by incubation at $37^{\circ} \mathrm{C}$ for $5 \mathrm{~min}$ and then $42^{\circ} \mathrm{C}$ for $60 \mathrm{~min}$. The reaction was terminated by incubation at $70^{\circ} \mathrm{C}$ for $10 \mathrm{~min}$. RT-PCR (Applied Biosystems; Thermo Fisher Scientific, Inc.) was performed using $2 \mu \mathrm{l}$ of cDNA, $12.5 \mu \mathrm{l}$ of TaqPCR Master Mix (Thermo Fisher Scientific, Inc.), $1 \mu 1$ of forward primers and $1 \mu \mathrm{l}$ of reverse primers (Table $\mathrm{I}$ ). $\mathrm{dH}_{2} \mathrm{O}$ was then added to produce a final volume of $25 \mu \mathrm{l}$ according to the manufacturer's protocol for 35 cycles. The thermocycling conditions used for RT-PCR were as follows: 35 cycles of $30 \mathrm{sec}$ at $94^{\circ} \mathrm{C}, 30 \mathrm{sec}$ at $60^{\circ} \mathrm{C}$ and $30 \mathrm{sec}$ at $72^{\circ} \mathrm{C}(31)$. The $2 \%$ agarose ( $2 \mathrm{~g}$ agarose to $100 \mathrm{ml}$ TAE buffer solution) was prepared and heated in a microwave in order to dissolve in TAE buffer. Then cooled it to $50^{\circ} \mathrm{C}$ and added $4 \mu \mathrm{l}$ ethidium bromide (0.1-0.2 pg/ml, Thermo Fisher Scientific, Inc.). The final RT-PCR products samples were performed for electrophoresis $(100 \mathrm{mV} 30 \mathrm{~min}$, Bio-Rad Bole Level 15x10 cm Sub-Cell GT Electrophoresis Cell 1704481). Finally, gel was imaged and analyzed (Image Lab 5.1; Bio-Rad Laboratories, Inc., Hercules, CA, USA).

Quantitative PCR ( $q P C R$ ). The RNA was isolated from ARPE-19 cells using the TRIzol reagent (Thermo Fisher Scientific, Inc.). In order to perform qPCR, a three-step amplifying protocol using SYBR Green Real-time PCR Master
Mixes (cDNA Synthesis kit; Thermo Fisher Scientific, Inc.), as well as 1,000 ng template cDNA, 12.5 $\mu \mathrm{l} \mathrm{SYBR} \mathrm{Green}$ Real-time PCR Master Mixes, and $0.5 \mu 1$ forward primers and $0.5 \mu \mathrm{l}$ reverse primers, which were diluted in a $25 \mu \mathrm{l}$ reaction volume. A StepOnePlus Real-Time PCR system was employed (Applied Biosystems; Thermo Fisher Scientific, Inc.). UCP2 and GAPDH primers were used in this experiment (Table I). The thermocycling conditions were as follows: $95^{\circ} \mathrm{C}$ for $10 \mathrm{~min}$; followed by 40 cycles of $95^{\circ} \mathrm{C}$ for $15 \mathrm{sec}$, $60^{\circ} \mathrm{C}$ for $30 \mathrm{sec}, 72^{\circ} \mathrm{C}$ for $32 \mathrm{sec}$; followed by $95^{\circ} \mathrm{C}$ for $15 \mathrm{sec}$, $60^{\circ} \mathrm{C}$ for $60 \mathrm{sec}$ and $95^{\circ} \mathrm{C}$ for $15 \mathrm{sec}$. Each sample was run and analyzed in triplicate. Expression levels were quantified using the $2^{-\Delta \Delta \mathrm{Cq}}$ method $(29,32)$.

Preparation of retinal tissues. The 40 one-week-old male C57BL/6 mice and $40 \mathrm{BALB} / \mathrm{c}$ mice weighing $30 \mathrm{~g}$ were used. Mice models were established using pre-protection with $5 \mu \mathrm{g}$ of PEDF injected into the vitreous cavity for $24 \mathrm{~h}$, followed by injection with $150 \mu \mathrm{M}$ of $\mathrm{H}_{2} \mathrm{O}_{2}$ to induce animal injury $(33,34)$. Mice were euthanized by dislocating their cervical spine. Following this, the eyes were enucleated, fixed in $4 \%$ paraformaldehyde at $4^{\circ} \mathrm{C}$ for $24 \mathrm{~h}$, washed with PBS and then embedded in paraffin. Sections were subsequently subjected to hematoxylin and eosin (H\&E) staining and immunocytochemistry.

$H \& E$ staining. H\&E staining was performed according to standard protocol (34). Briefly, following deparaffinization and rehydration, longitudinal sections $(5 \mu \mathrm{m})$ were stained with hematoxylin solution at $37^{\circ} \mathrm{C}$ for $5 \mathrm{~min}$, immersed five times in a solution of $1 \% \mathrm{HCl}$ and $70 \%$ ethanol and subsequently rinsed with distilled water. Sections were then stained with eosin solution at $37^{\circ} \mathrm{C}$ for $3 \mathrm{~min}$, dehydrated with alcohol and immersed in xylene. The slides were then examined and images were captured using a fluorescence microscope at x10 magnification (Thermo Fisher Scientific, Inc). The distance from the RPE layer to optic nerve head was measured, and the number of RPE cells was analyzed using Image-Pro Plus 6.0 software (Media Cybernetics, Inc., Rockville, MD, USA).

Immunofluorescence staining of cells and tissues. Cells were fixed with $3.7 \%$ formaldehyde in PBS at $4^{\circ} \mathrm{C}$ for $30 \mathrm{~min}$, rinsed in PBS three times and subsequently incubated at $37^{\circ} \mathrm{C}$ for $1 \mathrm{~h}$ with PBS containing $0.02 \%$ saponin and the following primary 


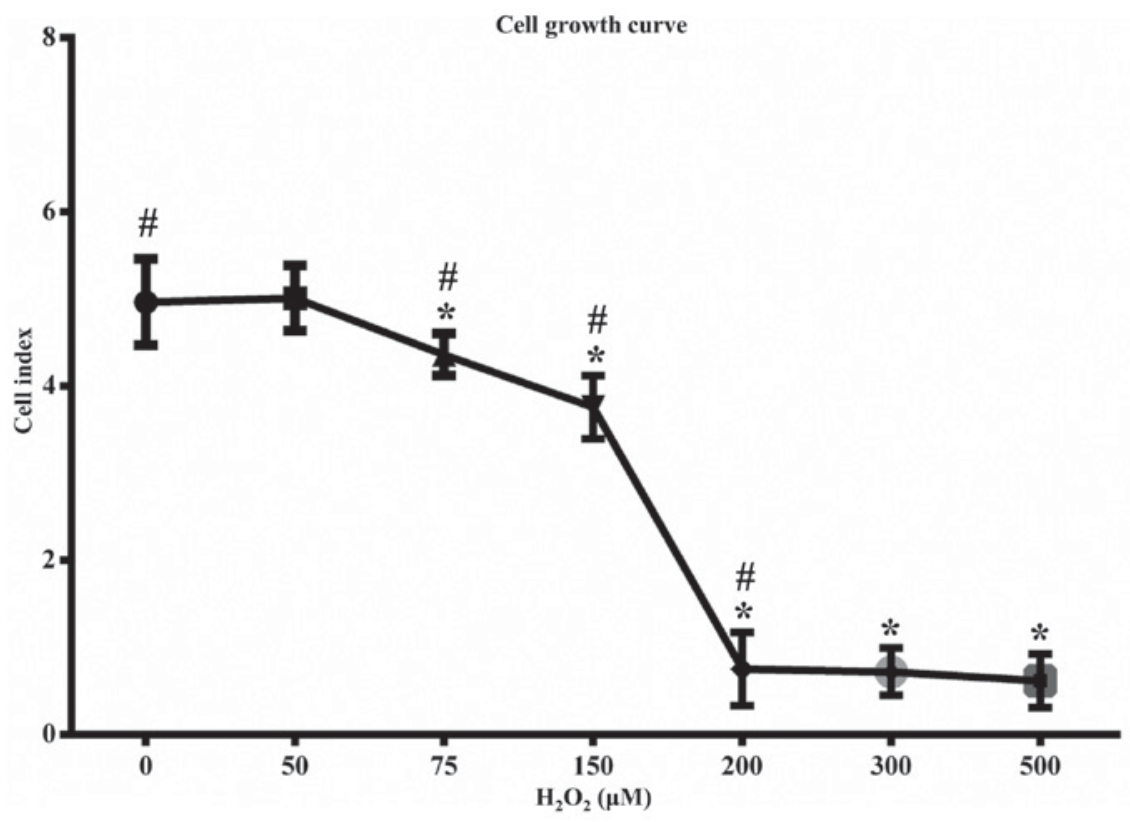

Figure 1. Determination of $\mathrm{H}_{2} \mathrm{O}_{2}$ working concentrations for the treatment of retinal pigment epithelium cells. ARPE-19 cell growth curves were plotted using an xCell-igence RTCA DP instrument and treated with different concentrations of $\mathrm{H}_{2} \mathrm{O}_{2}(0,50,75,150,200,300$ and $500 \mu \mathrm{M})$ for $24 \mathrm{~h}$. As concentrations of $\mathrm{H}_{2} \mathrm{O}_{2}$ increased, the number of viable cells decreased $(\mathrm{n}=6)$. There were significant differences between the viability of cells treated group with $75,150,200$, $300,500 \mu \mathrm{M} \mathrm{H}_{2} \mathrm{O}_{2}$ comparing with $0 \mu \mathrm{M} \mathrm{H}_{2} \mathrm{O}_{2}$ ( $\mathrm{n}=6$, ${ }^{*} \mathrm{P}<0.05$ vs. $0 \mu \mathrm{M} \mathrm{H}_{2} \mathrm{O}_{2}$ group). However, when the concentrations were 200,300 and $500 \mu \mathrm{M}$, the number of dead cells was so large that subsequent experiments could not be performed. So $\mathrm{H}_{2} \mathrm{O}_{2}$ working concentrations of $0,75,150$ and $200 \mu \mathrm{M}$ were selected for further experimentation ( $\left(\mathrm{H}_{2} \mathrm{O}_{2}\right.$ working concentrations).

antibodies: UCP2 (1:500; cat. no. ab77363; Abcam) and GFAP (1:500; cat. no. BA0056; Boster Biological Technology, Pleasanton, CA, USA). Following this, the cells were rinsed with PBS and incubated at $37^{\circ} \mathrm{C}$ for $1 \mathrm{~h}$ with fluorescence-labeled secondary antibodies (1:300; cat. no. CA21202S; Invitrogen; Thermo Fisher Scientific, Inc.). Cells were subsequently incubated with $\beta$-actin solution (100 ng/ml; Abcam) at $37^{\circ} \mathrm{C}$ for $10 \mathrm{~min}$ to stain the cytoskeleton. Following this, the slides were rinsed with distilled water and subsequently covered with Fluoromount- $G$ and a cover glass. The cells were then examined using a fluorescence microscope at $\mathrm{x} 40$ magnification.

The fresh tissues were fixed in $4 \%$ paraformaldehyde at $4^{\circ} \mathrm{C}$ for $48 \mathrm{~h}$. Paraffin-embedded eyeballs were removed and hydrated. The sections were microwaved in $0.01 \mathrm{~mol} / 1$ of sodium citrate buffer, cooled for $30 \mathrm{~min}$, washed in PBS and then blocked with $5 \%$ bovine serum albumin (cat. no. BA0056; Boster Biological Technology) at room temperature for $20 \mathrm{~min}$. Sections were then incubated overnight at $48^{\circ} \mathrm{C}$ with an antibody against UCP2 (1:100; cat. no. AP52232-100 $\mu$ g; Abgent, Inc., San Diego, CA, USA). Following rinsing with PBS, sections were then incubated with fluorescein isothiocyanate mice anti-human antibodies (1:200; cat. no. CA21202S; Invitrogen; Thermo Fisher Scientific, Inc.) at room temperature for $1 \mathrm{~h}$ in the dark. Following rinsing with PBS, sections were incubated with 4',6-diamidino-2-phenylindole $(1 \mathrm{mg} / \mathrm{ml})$ at $37^{\circ} \mathrm{C}$ for $10 \mathrm{~min}$, rinsed in PBS then and analyzed using a fluorescence microscope at x10 magnification.

Statistical analysis. All experiments were performed in triplicate. All data were analyzed using SPSS 18.0 software (SPSS, Inc., Chicago, IL, USA) and are presented as the mean \pm standard error of the mean. Differences between groups were analyzed via one-way analysis with post hoc contrasts by Student-Newman-Keuls test. $\mathrm{P}<0.05$ was considered to indicate a statistically significant difference.

\section{Results}

Effects of $\mathrm{H}_{2} \mathrm{O}_{2}$ ARPE-19 cell growth. Administration of $\mathrm{H}_{2} \mathrm{O}_{2}$ is a well-established model for the study of the OS mechanism in RPE cells $(30,35-38) . \mathrm{H}_{2} \mathrm{O}_{2}$ was applied to RPE cells to perform a cell growth curve experiment in order to determine the working concentrations resulting in consistent, high levels of cytotoxicity, which were defined as the level of $\mathrm{H}_{2} \mathrm{O}_{2}$ responsible for killing 50\% of the RPE cells following a $24 \mathrm{~h}$ incubation time period (30).

Cytotoxic effects of $\mathrm{H}_{2} \mathrm{O}_{2}$ on ARPE-19 cells were detected using various concentrations of $\mathrm{H}_{2} \mathrm{O}_{2}(0,50,75,150,200$, 300 and $500 \mu \mathrm{M})$. As presented in Fig. 1, the activity of the cells treated under 75, 150, 200, 300 and $500 \mu \mathrm{M} \mathrm{H}_{2} \mathrm{O}_{2}$ were significantly different from $0 \mu \mathrm{M} \mathrm{H}_{2} \mathrm{O}_{2}$ treated group. The number of viable cells was significantly decreased in a concentration-dependent manner. When the concentrations were 200, 300 and $500 \mu \mathrm{M}$, the number of dead cells was so large that subsequent experiments could not be performed. So the 0,75 , 150 and $200 \mu \mathrm{M}$ working treatment concentrations of $\mathrm{H}_{2} \mathrm{O}_{2}$ were selected for inclusion in subsequent experiments. The cells appeared notably smaller with increasing concentrations of $\mathrm{H}_{2} \mathrm{O}_{2}$, and the number of dead cells following additional treatment with PEDF was decreased compared with cells treated with $\mathrm{H}_{2} \mathrm{O}_{2}$ alone (Fig. 2).

PEDF protects cells against apoptosis during $\mathrm{H}_{2} \mathrm{O}_{2}$ injury. The cell growth curve results indicated that the viability of 
$\mathbf{H}$
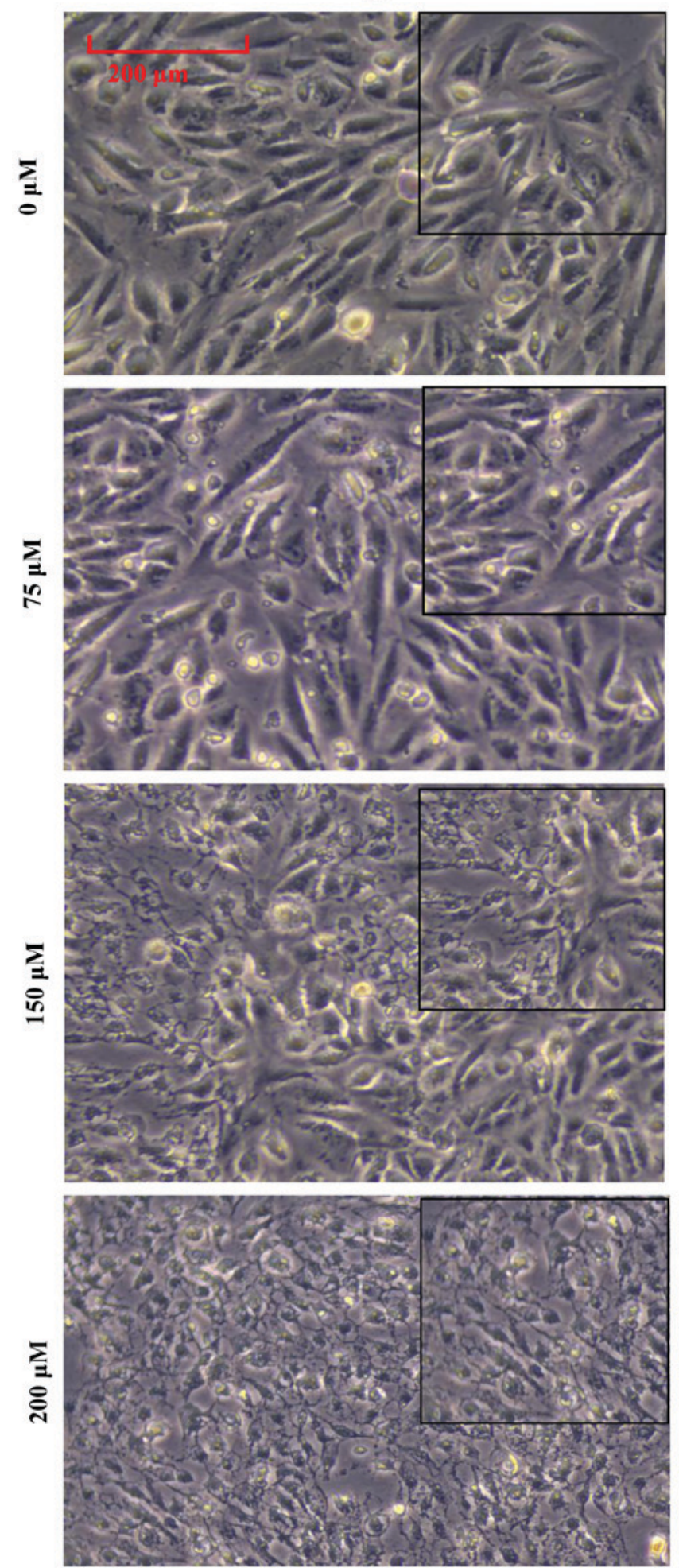

$\mathbf{P}+\mathbf{H}$
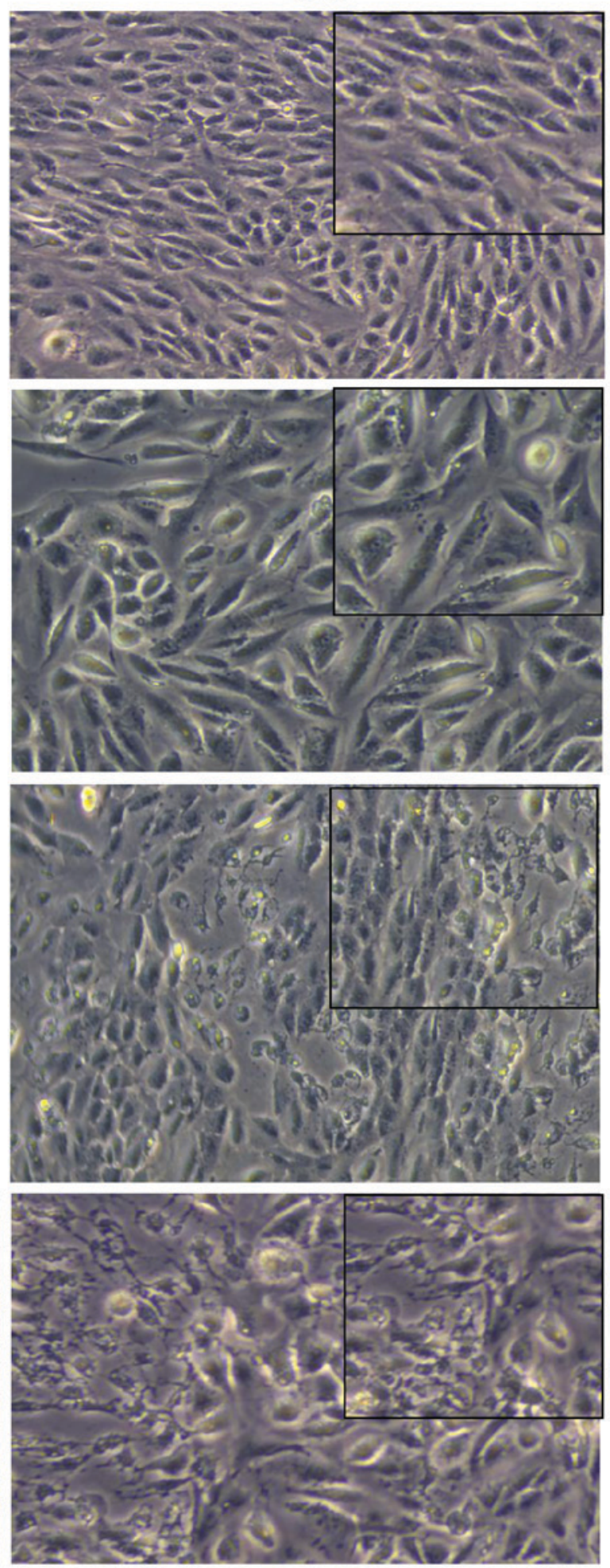

Figure 2. Phase-contrast micrographs of ARPE-19 cells following treatment with various concentrations of $\mathrm{H}_{2} \mathrm{O}_{2}$. With the increased concentration of $\mathrm{H}_{2} \mathrm{O}_{2}$ increased, the number of cells in the $\mathrm{H}$ group decreased. The morphology of cells became irregular and shrunken, with increased dead cells. Cells in the $\mathrm{P}+\mathrm{H}$ group were simultaneously treated with PEDF and various concentrations of $\mathrm{H}_{2} \mathrm{O}_{2}$, and the number of shrunken and apoptotic cells were decreased following treatment with PEDF. PEDF, pigment epithelium-derived factor; $\mathrm{H}, \mathrm{H}_{2} \mathrm{O}_{2}$ group; $\mathrm{P}+\mathrm{H}$, PEDF $+\mathrm{H}_{2} \mathrm{O}_{2}$ group. All large images, magnification x10 and the smaller square was $\mathrm{x} 20$.

RPE cells was significantly decreased following treatment with $\mathrm{H}_{2} \mathrm{O}_{2}$ in a dose-dependent manner (Fig. 1). When cells were treated with $0 \mu \mathrm{M} \mathrm{H}_{2} \mathrm{O}_{2}$, no change in cell viability was observed (data not shown). The activity of PEDF-treated cells was increased compared with cells treated with $\mathrm{H}_{2} \mathrm{O}_{2}$ alone; $25 \pm 4.5$ and $75 \pm 5.2 \%$ increase in cell number associated with PEDF-mediated protection following treatment with 75 and $150 \mu \mathrm{M} \mathrm{H}_{2} \mathrm{O}_{2}$, respectively $(\mathrm{P}<0.05$; Fig. $3 \mathrm{~A}$ and $\mathrm{B})$, whereas 

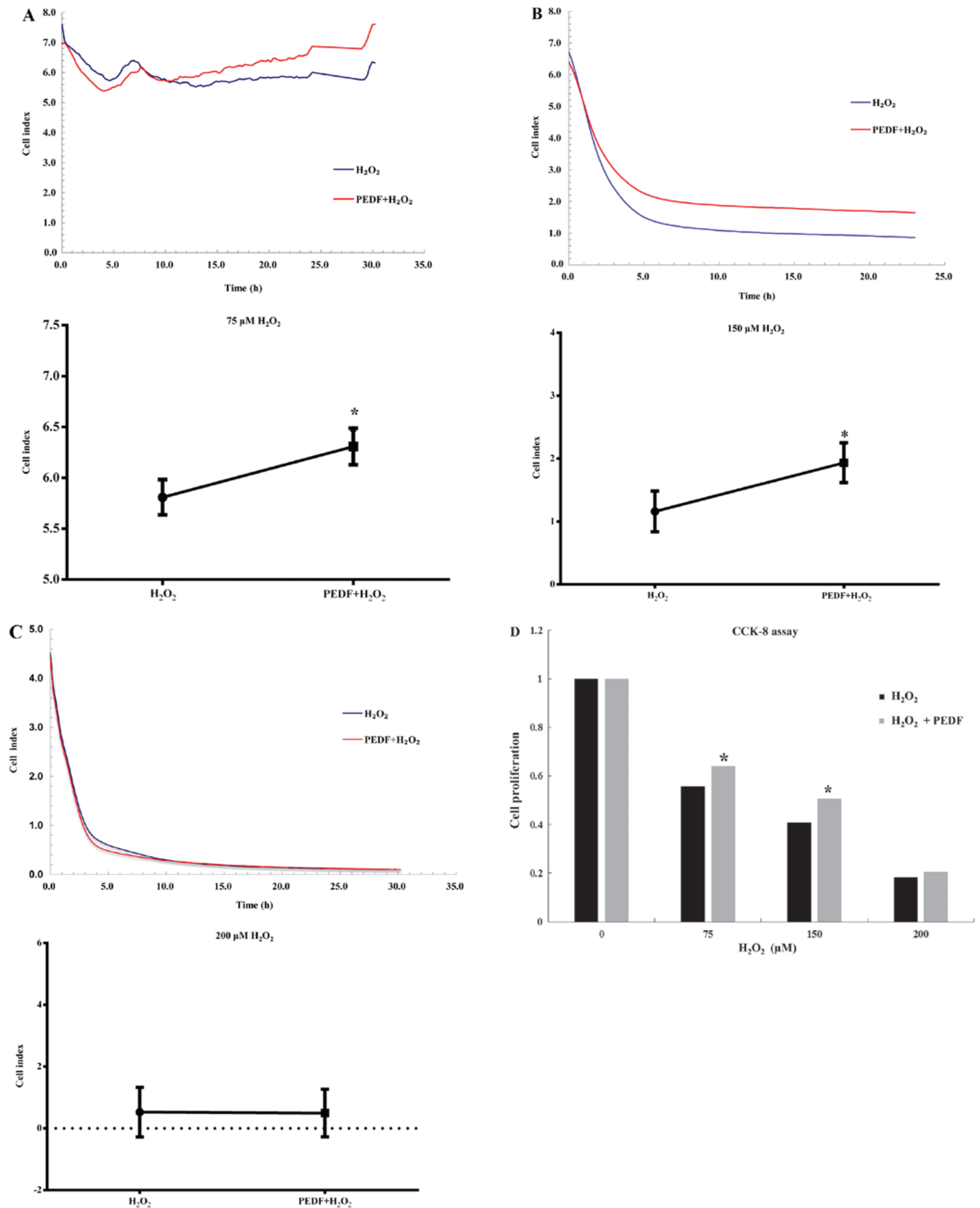

Figure 3. PEDF protects ARPE-19 cells from $\mathrm{H}_{2} \mathrm{O}_{2}$-induced cell death. Cells were divided into an oxidative group $\left(\mathrm{H}_{2} \mathrm{O}_{2}\right.$ treatment only) and a protective group (treatment with PEDF $+\mathrm{H}_{2} \mathrm{O}_{2}$ ). Following treatment for $24 \mathrm{~h}$, cell growth curves for both groups were analyzed. The results suggested that cell activity gradually decreased with the increasing concentrations of $\mathrm{H}_{2} \mathrm{O}_{2}$. (A and B) Cell viability following treatment with $\mathrm{H}_{2} \mathrm{O}_{2}+\mathrm{PEDF}$ was determined using an xCell-igence RTCA DP instrument, and the results were then quantitatively analyzed. When cells were treated with 75 and $150 \mu \mathrm{M}$ of $\mathrm{H}_{2} \mathrm{O}_{2}$, cell indexes exhibited by the PEDF $+\mathrm{H}_{2} \mathrm{O}_{2}$ group were increased compared with the group treated with $\mathrm{H}_{2} \mathrm{O}_{2}$ alone. Treatment with PEDF significantly increased the cell index value during oxidative stress injury $(\mathrm{P}<0.05 ; \mathrm{n}=6)$. (C) When cells were treated with $200 \mu \mathrm{M}$ of $\mathrm{H}_{2} \mathrm{O}_{2}$, no significant difference between the cell indexes exhibited by the two groups was observed $(\mathrm{P}>0.05 ; \mathrm{n}=6)$. (D) ARPE-19 cell viability was further investigated using a CCK-8 assay. Cell proliferation gradually decreased as the concentration of $\mathrm{H}_{2} \mathrm{O}_{2}$ increased, while the viability of the PEDF treated group cells increased compared with cells treated with $\mathrm{H}_{2} \mathrm{O}_{2}$ alone $(\mathrm{P}<0.05 ; \mathrm{n}=6)$. ${ }^{*} \mathrm{P}<0.05$ vs. $\mathrm{H}_{2} \mathrm{O}_{2}$ group. CCK-8, Cell Counting Kit-8; PEDF, pigment epithelium-derived factor. 
A

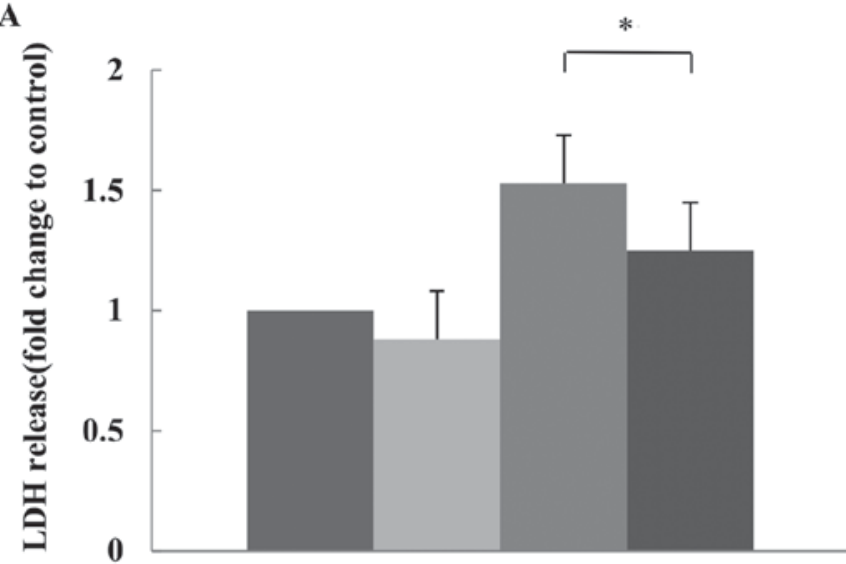

m control

$=$ PEDF $(200 \mathrm{ng} / \mathrm{ml})$

$=\mathrm{H}_{2} \mathrm{O}_{2}(150 \mu \mathrm{M})$

- PEDF $(200 \mathrm{ng} / \mathrm{ml})+\mathrm{H}_{2} \mathrm{O}_{2}(150 \mu \mathrm{M})$

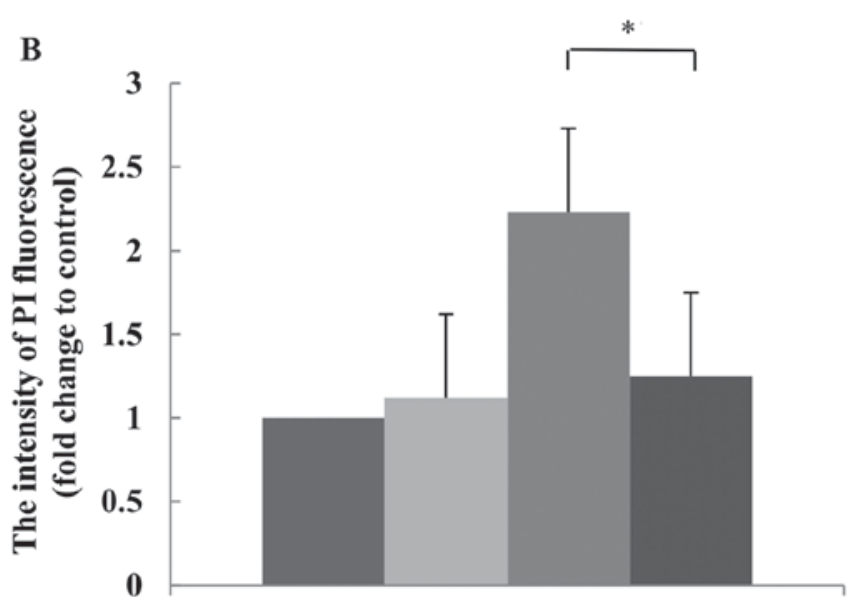

a control

= PEDF (200 ng/ml)

$=\mathrm{H}_{2} \mathrm{O}_{2}(150 \mu \mathrm{M})$

= PEDF $(200 \mathrm{ng} / \mathrm{ml})+\mathrm{H}_{2} \mathrm{O}_{2}(150 \mu \mathrm{M})$

Figure 4. PEDF protects cells against apoptosis during $\mathrm{H}_{2} \mathrm{O}_{2}$ injury. (A) $\mathrm{LDH}$ assays demonstrated an increase in LDH release following treatment with $150 \mu \mathrm{M}$ $\mathrm{H}_{2} \mathrm{O}_{2}$; however, this effect was significantly attenuated following treatment with PEDF. (B) PI staining also revealed the extent of $\mathrm{H}_{2} \mathrm{O}_{2}$ toxicity, and that cell death induced by oxidative stress was attenuated by PEDF $(n=6)$. "P $<0.05$ vs. $\mathrm{H}_{2} \mathrm{O}_{2}$ group. PI, propidium iodide; LDH, lactate dehydrogenase; PEDF, pigment epithelium-derived factor.

cells treated with $200 \mu \mathrm{M} \mathrm{H}_{2} \mathrm{O}_{2}+$ PEDF did not exhibit a marked change in activity compared with cells treated with $200 \mu \mathrm{M}$ alone (Fig. 3C). Cell proliferation was also investigated via CCK-8 assays (Fig. 3D). The results indicated that treatment with PEDF (75 and $150 \mu \mathrm{M}$ ) significantly protected cells from $\mathrm{H}_{2} \mathrm{O}_{2}$-induced injury; there was no difference between different concentrations in the $\mathrm{H}_{2} \mathrm{O}_{2}$-treated groups (75-200 $\mu \mathrm{M}$; P>0.05; Fig. 3D).

The sensitivity of RPE cells to $\mathrm{H}_{2} \mathrm{O}_{2}$ toxicity was more severe with increasing donor cell passages (29). In addition, PEDF treatment was revealed to significantly suppress cytotoxicity, as determined via LDH release (Fig. 4A) and PI staining (Fig. 4B) assays. The results of LDH release assays demonstrated that OS alone increased cytotoxicity by $\sim 55 \pm 9.6 \%$, whereas treatment with PEDF lowered OS-associated cell death by $\sim 40 \pm 6.4 \%$, compared with the $\mathrm{H}_{2} \mathrm{O}_{2}$-treated group $(\mathrm{P}<0.05)$. The result was further supported by PI staining, which indicated the number of dead cells (Fig. 4); however, differences between the $\mathrm{PEDF}+\mathrm{H}_{2} \mathrm{O}_{2}$ and $\mathrm{H}_{2} \mathrm{O}_{2}$ alone groups were additionally demonstrated to be significant $(\mathrm{P}<0.05)$.

PEDF regulates the expression of genes associated with apoptosis. OS-induced apoptosis was also investigated via detection of apoptotic gene expression. The expression levels of caspase 3 and Bax, both of which are associated with apoptosis, were significantly enhanced following administration of $\mathrm{H}_{2} \mathrm{O}_{2}$, exhibiting $1.2 \pm 0.4$ - and $1.46 \pm 0.5$-fold changes compared with the untreated group, respectively; however, the expression levels of the anti-apoptotic gene $\mathrm{Bcl} 2$ were suppressed following administration of $\mathrm{H}_{2} \mathrm{O}_{2}$ by $1.25 \pm 0.2$-fold change (Fig. 5). PEDF reversed these effects, and induced a decrease in caspase 3 and Bax levels by $1.0 \pm 0.4$-fold and $0.9 \pm 0.3$-fold, respectively; an increase in $\mathrm{Bcl} 2$ expression levels by $1.5 \pm 0.2$-fold was observed $(\mathrm{P}<0.05$; Fig. 5$)$. No marked differences were observed between the PEDF and control groups ( $\mathrm{P}>0.05$; Fig. 5).

UCP2 mRNA levels in ARPE-19 cells during OS in the presence or absence of PEDF treatment. UCP2 mRNA expression in cells treated with $\mathrm{H}_{2} \mathrm{O}_{2}$ in the presence or absence of PEDF was investigated by RT-sqPCR. The results demonstrated no significant differences in UCP2 mRNA expression levels between different $\mathrm{H}_{2} \mathrm{O}_{2}$ treatment groups ( $\mathrm{P}>0.05$; Fig. 6). However, treatment with PEDF significantly increased the mRNA UCP2 levels by $33 \pm 3.2$ and $45 \pm 4.6 \%$ in cells treated with 75 and $150 \mu \mathrm{M} \mathrm{H}_{2} \mathrm{O}_{2}$, respectively ( $\mathrm{P}=0.001$; Fig. 6).

We also confirmed this result using qPCR. The results demonstrated that levels of UCP2 in PEDF+ $\mathrm{H}_{2} \mathrm{O}_{2}$ groups 
A
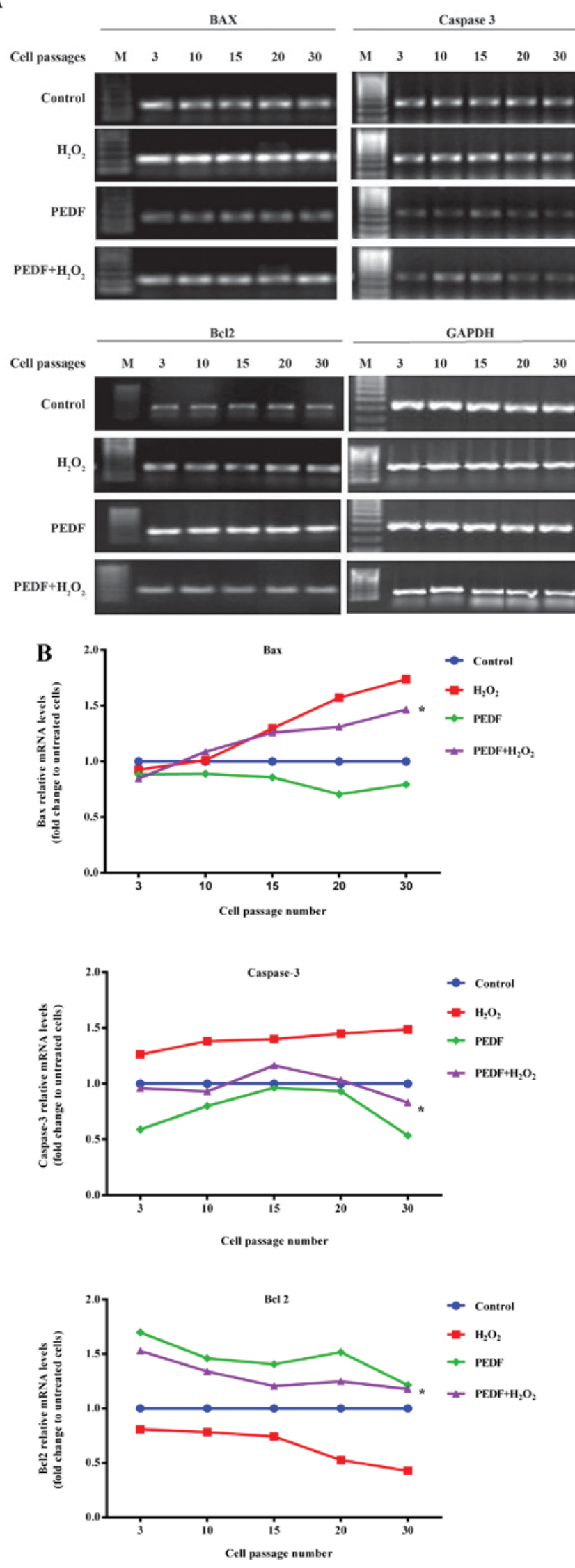

Figure 5. PEDF regulates the expression of genes associated with apoptosis (A and $\mathrm{B}$ ) The results of reverse transcription-semi-quantitative polymerase chain reaction analyses demonstrated that PEDF attenuated the effects of oxidative stress on caspase 3 , Bax and $\mathrm{Bcl} 2$ gene expression levels $(\mathrm{n}=6)$. ${ }^{*} \mathrm{P}<0.05$ vs. $\mathrm{H}_{2} \mathrm{O}_{2}$ group. PEDF, pigment epithelium-derived factor; $\mathrm{Bcl} 2$, B cell lymphoma 2; Bax, Bcl2 associated X.

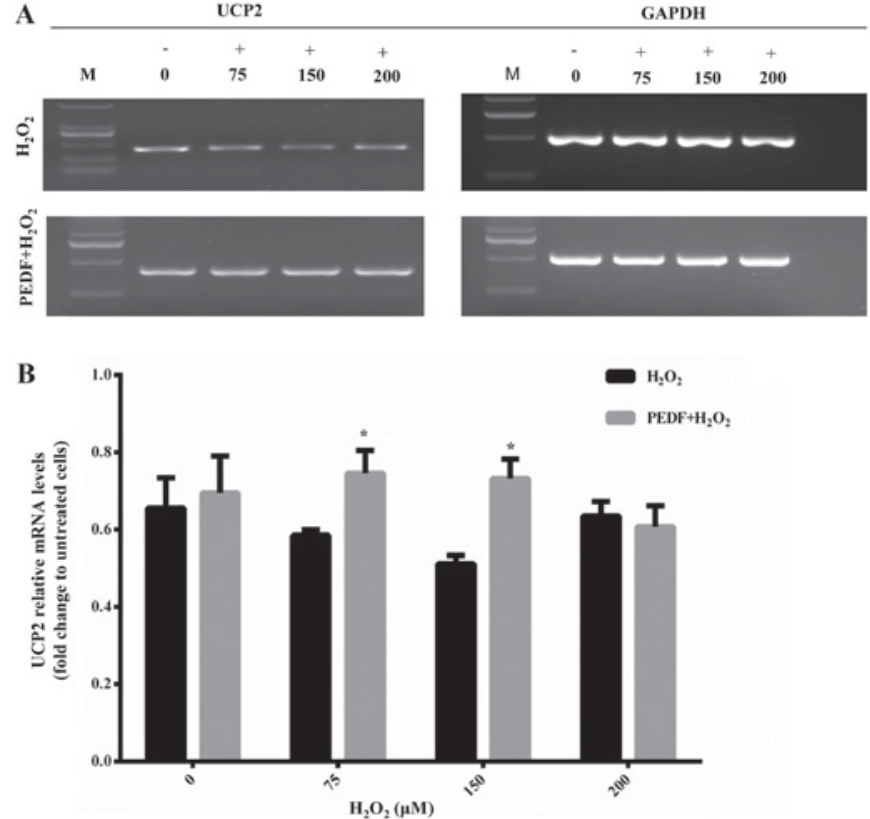

Figure 6. Determination of UCP2 mRNA levels by (A) reverse transcription semi-quantitative polymerase chain reaction after treatment with $200 \mathrm{ng}$ PEDF $+\mathrm{H}_{2} \mathrm{O}_{2}$ for $24 \mathrm{~h}$, or $\mathrm{H}_{2} \mathrm{O}_{2}$ alone for $24 \mathrm{~h}$, followed by (B) densitometry analysis of PCR for UCP2. GAPDH served as the loading control. The results demonstrated that UCP2 gene expression in cells treated with PEDF was increased compared with the $\mathrm{H}_{2} \mathrm{O}_{2}$ group $(n=6)$. In addition, there were no significant differences in UCP2 expression levels exhibited by cells treated with various concentrations of $\mathrm{H}_{2} \mathrm{O}_{2}$. ${ }^{*}<0.05$ vs. $\mathrm{H}_{2} \mathrm{O}_{2}$ group. $\mathrm{UCP} 2$, uncoupling protein 2; PEDF, pigment epithelium-derived factor.

were significantly increased by $52 \pm 2.7$ and $45 \pm 3.5 \%$ compared with groups treated with 75 and $150 \mu \mathrm{M} \mathrm{H}_{2} \mathrm{O}_{2}$, respectively $(\mathrm{P}<0.05$; Fig. 7), while no statistical differences were revealed between different $\mathrm{H}_{2} \mathrm{O}_{2}$-treated cell groups.

PEDF protects RPE cells and tissues from OS-induced damage. OS-induced regulation of UCP2 expression levels was investigated using a UCP2 antibody, which revealed increased UCP2 expression in RPE cells following treatment with PEDF (Fig. 8A and B). Furthermore, the results demonstrated that PEDF increased the expression of UCP2 in the RPE layer compared with the untreated $\mathrm{H}_{2} \mathrm{O}_{2}$-alone treatment groups (Fig. 9).

Injury to the RPE layers during OS was reduced by treatment with PEDF. According to the H\&E staining results, the thickness of RPE layer in the $\mathrm{H}_{2} \mathrm{O}_{2}$-injured group was markedly decreased compared with the negative group (no treatment), whereas treatment with PEDF treatment markedly attenuated this effect (Fig. 10A and B). The thickness of RPE layers in the C57BL/6 mice was measured at different distances from the optic disk, and the results demonstrated that the thicknesses were significantly increased in layers treated with PEDF during OS (Fig. 10C). This was also demonstrated in Fig. 10D, which revealed that the number of RPE cells increased by $2.25 \pm 0.3$-fold following treatment with PEDF compared with cells treated with $\mathrm{H}_{2} \mathrm{O}_{2}$ alone $(\mathrm{P}<0.05)$. These results suggest PEDF alone group may have no marked protection in the control group cell. The BALB/c mice were used only to verify the results and confirm the same results with C57BL/6 mice. Therefore only the results of C57BL/6 mice were analyzed. 

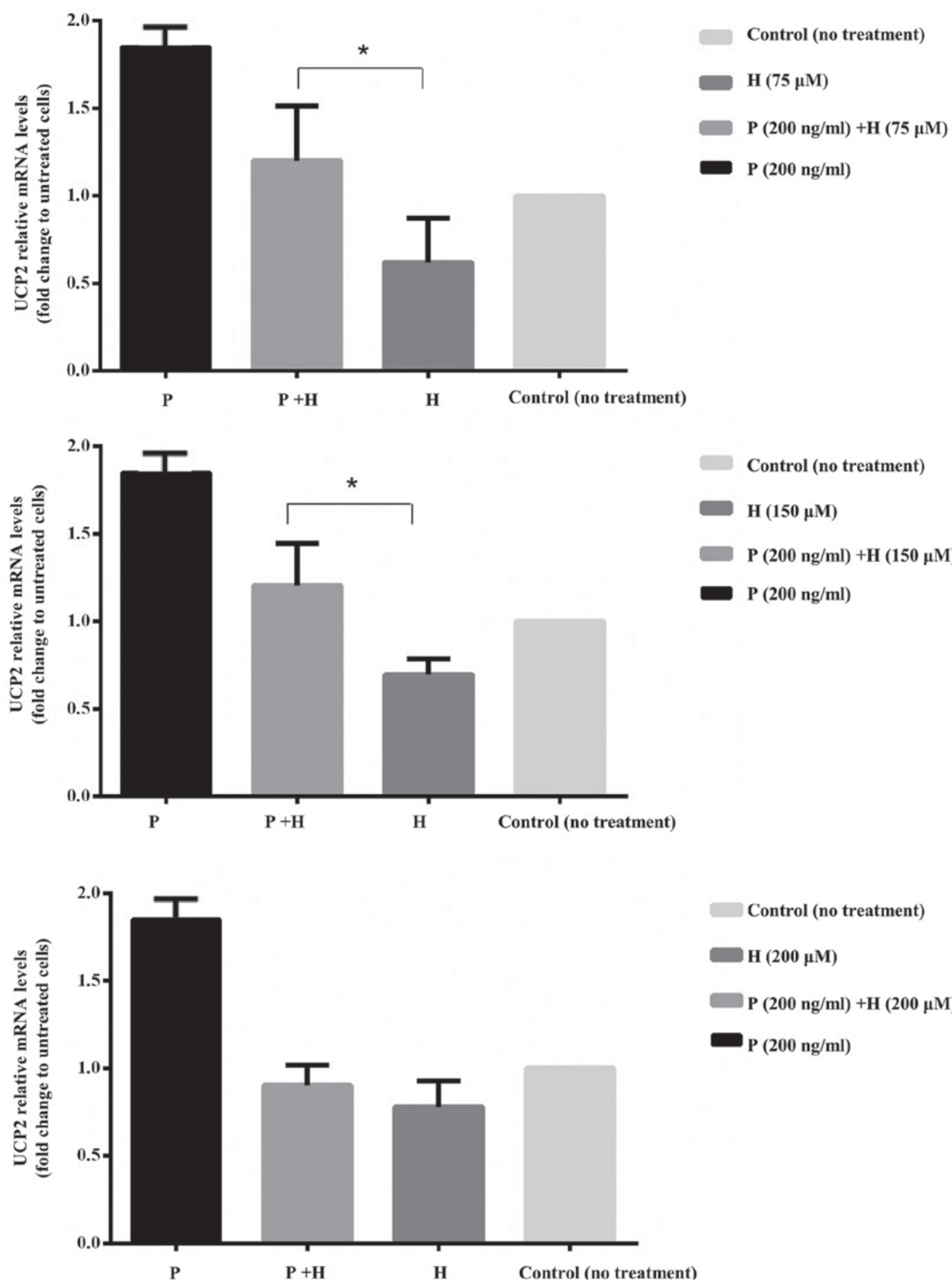

Figure 7. Expression levels of UCP2 mRNA were determined via quantitative polymerase chain reaction. The results demonstrated that PEDF attenuated the effects of oxidative stress by increasing UCP2 expression. Expression levels of UCP2 in the PEDF protective group and the oxidative group were significantly different $(n=6) .{ }^{*} \mathrm{P}<0.05$. UCP2, uncoupling protein 2; PEDF, pigment epithelium-derived factor.

\section{Discussion}

In the present study, PEDF was revealed to effectively protect RPE cells and tissues from OS injury. Increasing evidence from basic and clinical studies $(39,40)$ has indicated that oxidative damage severely affects the pathogenesis of AMD (41). Cumulative oxidative damage represents the underlying mechanism of aging, as well as various diseases, including Alzheimer's disease $(42,43)$, Parkinson's disease and age-related macular degeneration (44). We have previously reported that human RPE cells are increasingly sensitive to OS in an age-dependent manner, and mitochondrial dysfunction induces cell vulnerability to stress $(45,46)$. In a previous study, UCP2 expression in arcuate neurons induces mitochondrial alterations, and enhanced UCP2 activity decreases the production and availability of oxygen free radicals (47). As a sensor of mitochondrial OS, UCP2 is an important factor of local feedback mechanisms that regulate mitochondrial 

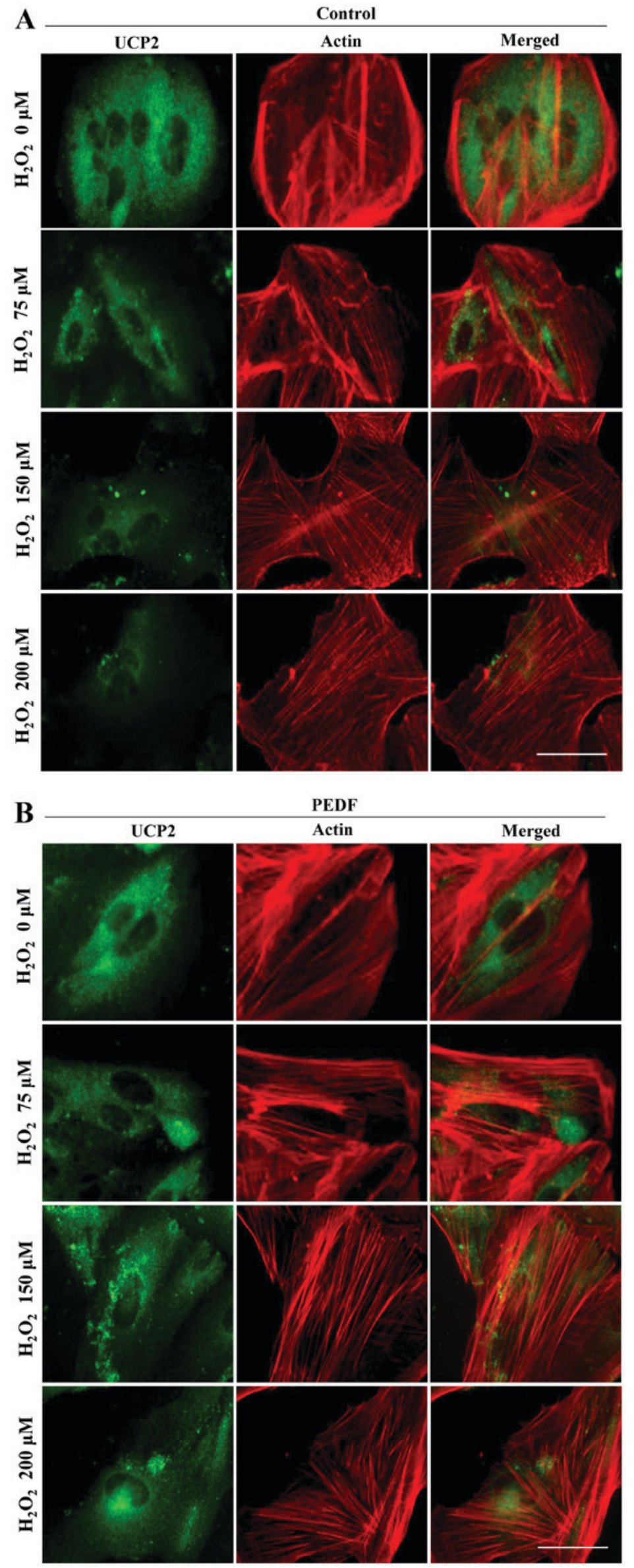

Figure 8. PEDF protects retinal pigment epithelium cells and tissues from OS-induced damage. (A and B) Immunofluorescence labeling assay results revealed that UCP2 expression was decreased during $\mathrm{H}_{2} \mathrm{O}_{2}$-induced cell injury in a concentration-dependent manner; however, treatment with PEDF attenuated this effect. Scale bar=30 $\mu \mathrm{m}$. PEDF, pigment epithelium-derived factor; UCP2, uncoupling protein 2. 

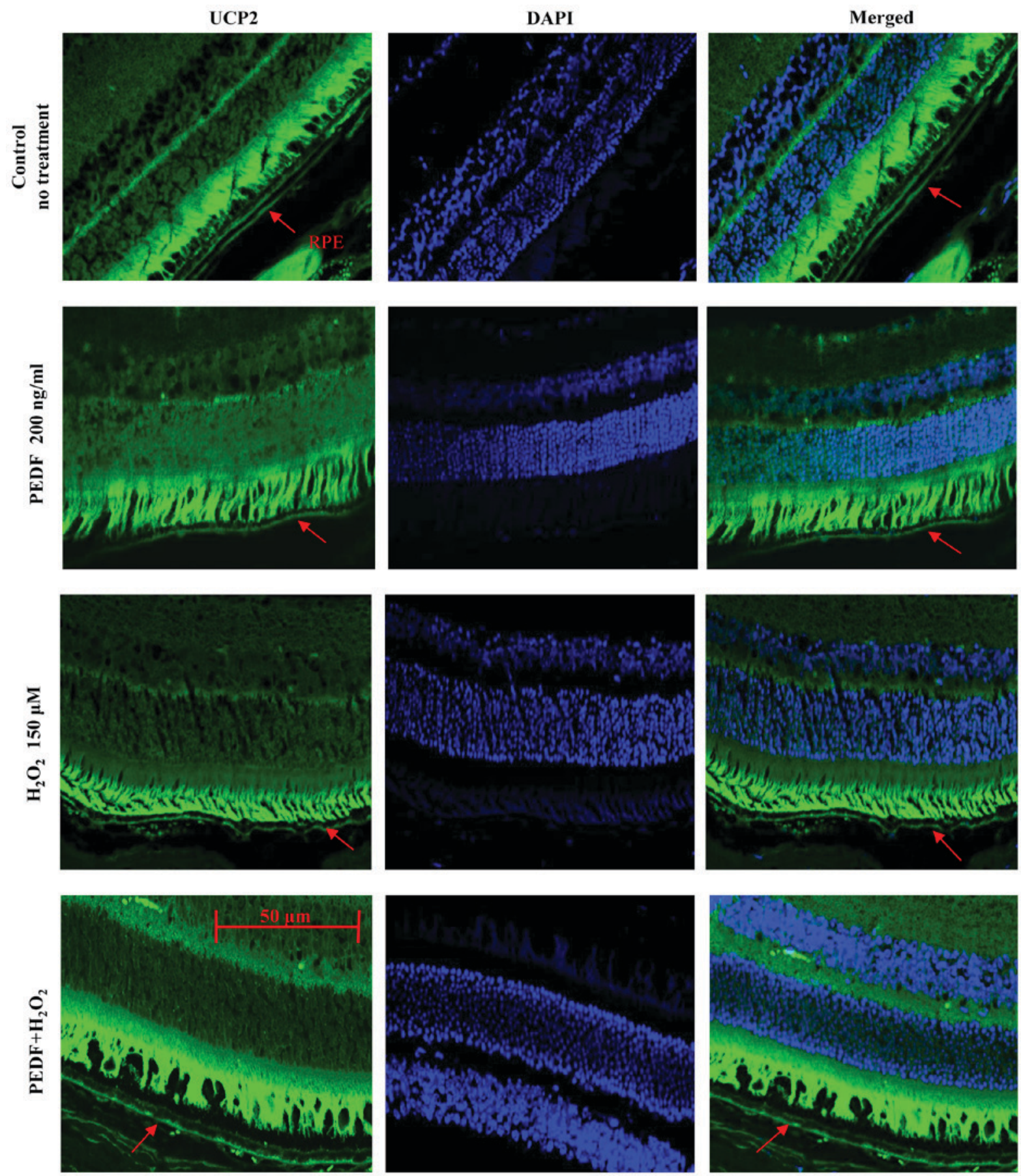

Figure 9. Combined UCP2 (green fluorescence) and DAPI (blue fluorescence) labeling of retinal tissues post-treatment. The fluorescence intensity of UCP2 in the retinal pigment epithelium layer following pre-treatment with $200 \mathrm{ng}$ of PEDF $+150 \mu \mathrm{m}$ of $\mathrm{H}_{2} \mathrm{O}_{2}$ was enhanced compared with cells treated with $\mathrm{H}_{2} \mathrm{O}_{2}$. Red arrows represent the retinal pigment epithelium layer (scale bar=50 $\mu \mathrm{m}$ ). UCP2, uncoupling protein 2; DAPI, 4'6-diamidino-2-phenylindole; PEDF, pigment epithelium-derived factor.

ROS production (20). Furthermore, previous data has revealed that PEDF decreases age-induced sensitivity of RPE cells to $\mathrm{H}_{2} \mathrm{O}_{2}$ toxicity and maintains mitochondrial function in RPE cells during OS (36). PEDF has been demonstrated to be an important protein for retinal survival and function (48-50). Considering that PEDF is expressed and secreted by RPE cells, it may undertake an autocrine protective mechanism that protects cells from OS-induced damage (51).

Culturing of RPE cells with $\mathrm{H}_{2} \mathrm{O}_{2}$ has been well established to represent an effective model for the study of OS and the effects of anti-apoptotic effectors $(29,52,53)$. Following the treatment of cells with $\mathrm{H}_{2} \mathrm{O}_{2}(0,75,150$ and $200 \mu \mathrm{M})$, the results of the present study demonstrated that PEDF had a protective effect against OS following treatment with 75 and $150 \mu \mathrm{M} \mathrm{H}_{2} \mathrm{O}_{2}$; however, PEDF did not exhibit a significant protective effect following treatment with $200 \mu \mathrm{M} \mathrm{H}_{2} \mathrm{O}_{2}$. In the present study, cell viability and proliferation were investigated by performing cell growth curve experiments, and CCK-8, LDH and PI staining assays, and the results revealed that PEDF protected cells from $\mathrm{H}_{2} \mathrm{O}_{2}$-induced cell 
A Retina layers of $\mathrm{C} 57 \mathrm{BL} / 6$ mice
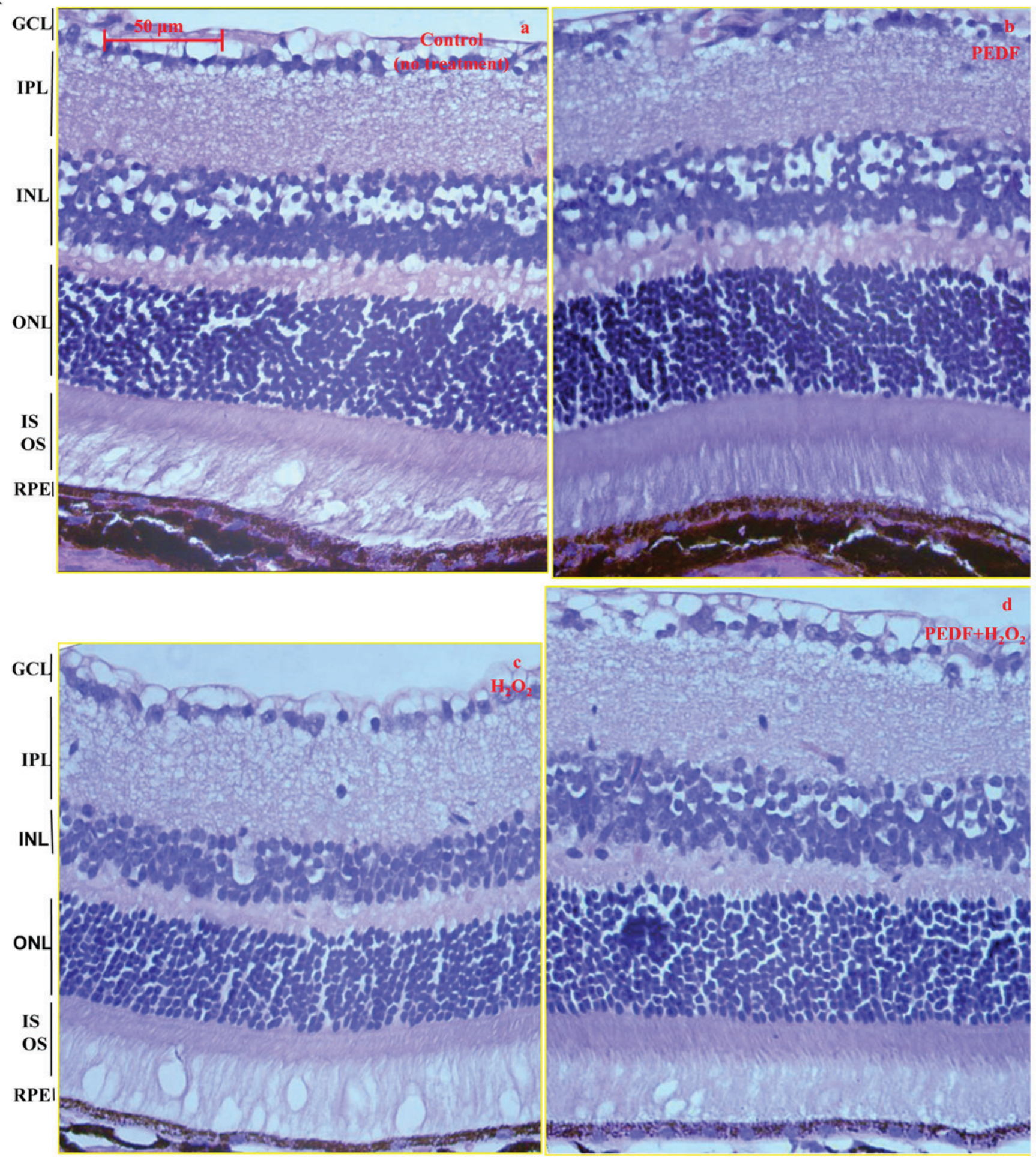

Figure 10. Representative microstructure and histological images obtained following H\&E staining demonstrated the morphological effects of various treatments on RPE layers in animal models. C57BL/6 mice and BALB/c mice were treated with or without $5 \mu \mathrm{g}$ of PEDF and $150 \mu \mathrm{M}$ of $\mathrm{H}_{2} \mathrm{O}_{2}$.

death and PEDF increased cell viability following $\mathrm{H}_{2} \mathrm{O}_{2}$ treatment. The expression levels of apoptosis-associated caspase 3 and Bax genes were suppressed following treatment with $\mathrm{PEDF}$, and the expression of the anti-apoptotic gene $\mathrm{Bcl} 2$ was increased, which suggested that the PEDF pathway is associated with cell survival during OS. In the present study, it was also revealed that treatment with PEDF significantly affected UCP 2 mRNA and protein expression levels. In the animal model, the thickness of the RPE layer was increased post-treatment with PEDF compared with the $\mathrm{H}_{2} \mathrm{O}_{2}$ group, which supports our hypothesis that PEDF protects RPE tissue via upregulation of the mitochondrial inner membrane protein, UCP2. Previously, it has been reported that PEDF attenuated dendrite extension defective protein-induced apoptosis in pre-MC3T3-E1 osteoblasts (54). This study has also reported that PEDF attenuates endothelial injury by inhibiting 

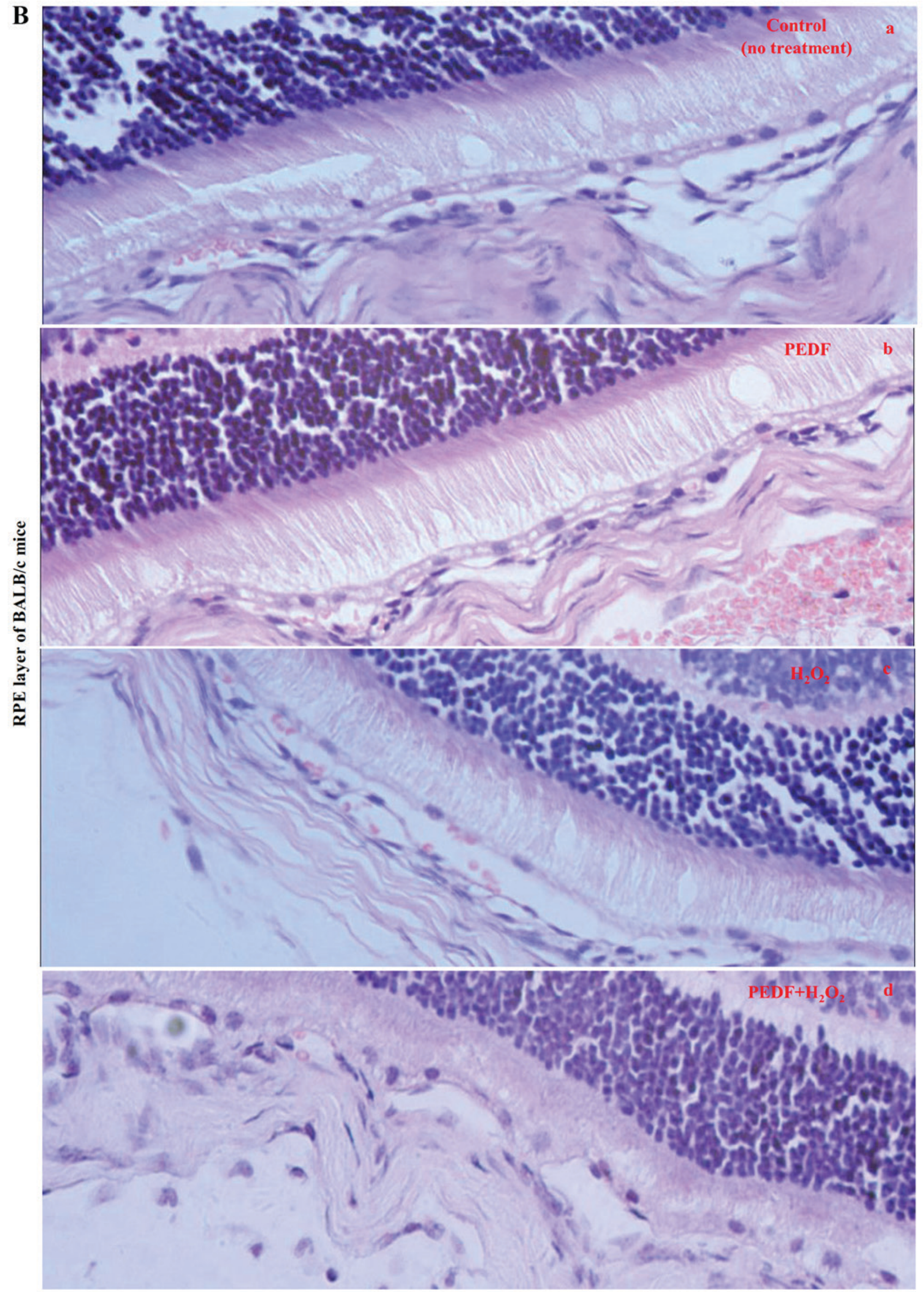

Figure 10. Continued. The histological images of H\&E staining revealed that the thickness of RPE layers obtained from (A) C57BL/6 mice and (B) BALB/c mice treated with $\mathrm{H}_{2} \mathrm{O}_{2}$ alone were thinner compared with other treatment groups; however, this was markedly attenuated following treatment with PEDF during oxidative stress. 

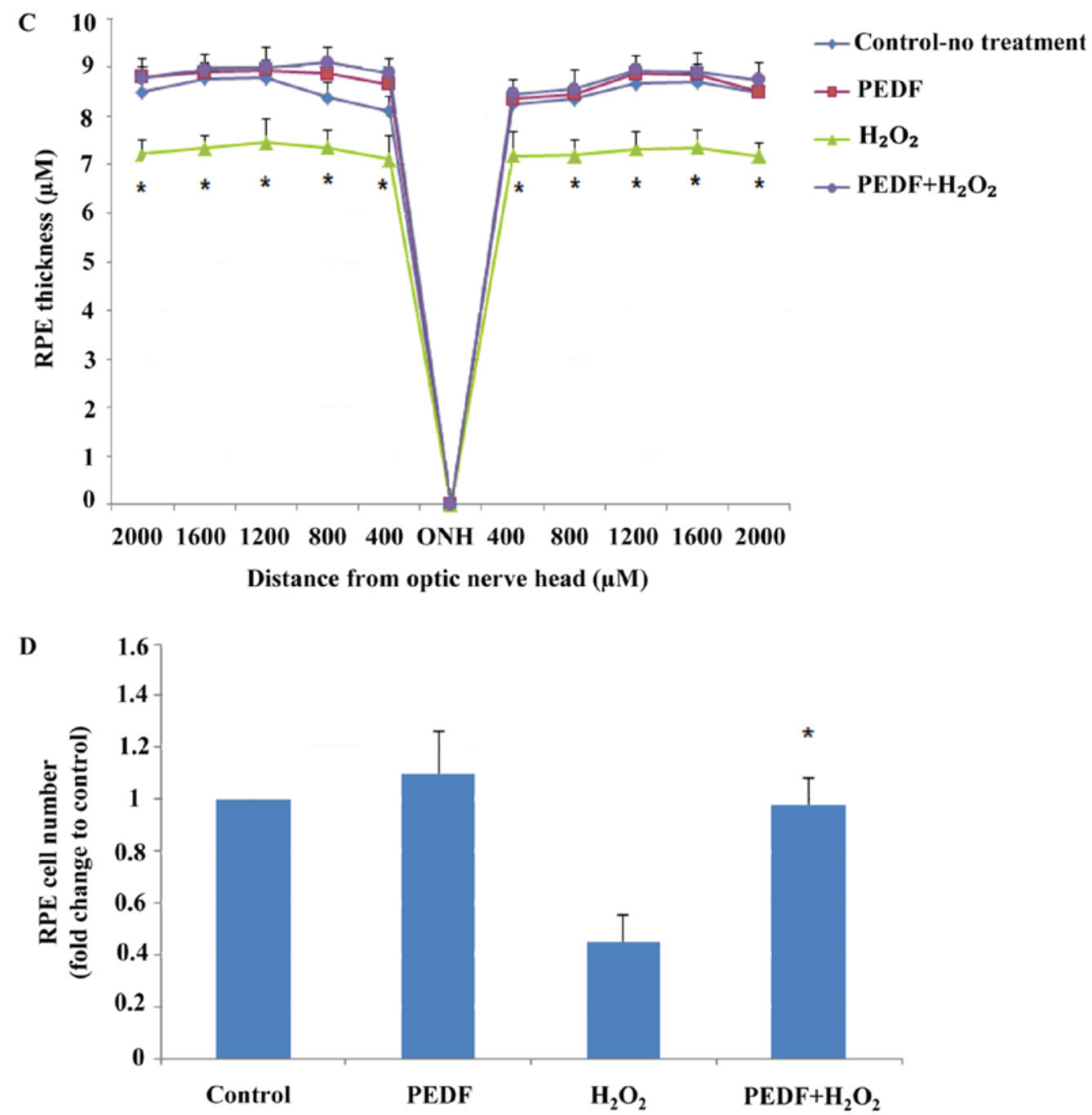

Figure 10. Continued. (C and D) Quantitative analysis of C57BL/6 mice to make the comparison of $\mathrm{PEDF}+\mathrm{H}_{2} \mathrm{O}_{2}$ group vs. the $\mathrm{H}_{2} \mathrm{O}_{2}$ group ( $\mathrm{n}=6$; $\mathrm{P}<0.05$ vs. the $\mathrm{H}_{2} \mathrm{O}_{2}$ group). $\mathrm{H} \& \mathrm{E}$, hematoxylin and eosin; PEDF, pigment epithelium-derived factor. RPE, retinal pigment epithelium; OS, outer segment; IS, inner segment; ONL, outer nuclear layer; INL, inner nuclear layer; IPL, inner plexiform layer; GCL, ganglion cell layer.

Wnt/ $\beta$-catenin pathways, which subsequently suppresses the OS response (55). Considering the published study report that (47) UCP2 regulates mitochondrial ROS production and suppresses ATP generation, it was hypothesized that PEDF protects RPE cells during OS, partly by increasing the expression levels of UCP2.

In conclusion, the present study demonstrated that PEDF may protect human ARPE-19 cells against $\mathrm{H}_{2} \mathrm{O}_{2}$-induced OS both in vitro and in vivo. Therefore, PEDF may represent a potential therapeutic agent for the prevention of AMD-associated visual damage.

\section{Acknowledgements}

Not applicable.

\section{Funding}

This study was supported by grants from the National Natural Science Foundation of China (grant nos. 81100665 and 81770929).

\section{Availability of data and materials}

The datasets used and/or analyzed during the current study are available from the corresponding author on reasonable request.

\section{Authors' contributions}

YH conceived and designed the study. She also reviewed and edited the manuscript. XG guided all the experiments and provided the laboratory. XW performed all experiments and wrote the paper. XL, YR, YL, SH and JZ performed the experiments. All authors read and approved the manuscript.

\section{Ethics approval and consent to participate}

The present study was approved by the Xi'an Jiao Tong University Animal Research Committee (Xi'an, China).

\section{Patient consent for publication}

Not applicable. 


\section{Competing interests}

The authors declare they have no competing interests.

\section{References}

1. Klein R and Klein BE: The prevalence of age-related eye diseases and visual impairment in aging: Current estimates. Invest Ophthalmol Vis Sci 54: ORSF5-ORSF13, 2013.

2. Jermak CM, Dellacroce JT, Hefez J and Peyman GA: Triam cinolone acetonide in ocular therapeutics. Surv Ophthalmol 52: 503-522, 2007

3. Yu CC, Nandrot EF, Ying D and Finnemann SC: Dietary antioxidants prevent age-related retinal pigment epithelium actin damage and blindness in mice lacking $\alpha v \beta 5$ integrin. Free Radic Biol Med 52: 660-670, 2012.

4. Khandhadia S and Lotery A: Oxidation and age-related macular degeneration: Insights from molecular biology. Expert Rev Mol Med 12: e34, 2010.

5. Jarrett S G and Boulton ME: Consequences of oxidative stress in age-related macular degeneration. Mol Aspects Med 33: 399-417, 2012.

6. Mettu PS, Wielgus AR, Ong SS and Cousins SW: Retinal pigment epithelium response to oxidant injury in the pathogenesis of early age-related macular degeneration. Mol Aspects Med 33: 376-398, 2012.

7. Golestaneh N, Chu Y, Xiao YY, Stoleru GL and Theos AC: Dysfunctional autophagy in RPE, a contributing factor in age-related macular degeneration. Cell Death Dis 8: e2537, 2017.

8. Bailey TA, Kanuga N, Romero IA, Greenwood J, Luthert PJ and Cheetham ME: Oxidative stress affects the junctional integrity of retinal pigment epithelial cells. Invest Ophthalmol Vis Sci 45 675-684, 2004

9. Strunnikova N, Zhang C, Teichberg D, Cousins SW, Baffi J, Becker KG and Csaky KG: Survival of retinal pigment epithelium after exposure to prolonged oxidative injury: A detailed gene expression and cellular analysis. Invest Ophthalmol Vis Sci 45: 3767-3777, 2004.

10. Mailloux RJ and Harper ME: Uncoupling proteins and the control of mitochondrial reactive oxygen species production. Free Radic Biol Med 51: 1106-1105, 2011.

11. Collins S, Pi J and Yehuda-Shnaidman E: Uncoupling and reactive oxygen species (ROS)-A double-edged sword for $\beta$-cell function? 'Moderation in all things'. Best Pract Res Clin Endocrinol Metab 26: 753-758, 2012.

12. Casteilla L, Rigoulet M and Pénicaud L: Mitochondrial ROS metabolism: Modulation by uncoupling proteins. IUBMB Life 52: 181-188, 2010.

13. Andrews ZB, Horvath B, Barnstable CJ, Elsworth J, Yang L, Beal MF, Roth RH, Matthews RT and Horvath TL: Uncoupling protein-2 is critical for nigral dopamine cell survival in a mouse model of Parkinson's disease. J Neurosci 25: 184-191, 2005

14. Trenker M, Malli R, Fertschai I, Levakfrank S and Graier WF Uncoupling proteins 2 and 3 are fundamental for mitochondrial $\mathrm{Ca}^{2+}$ uniport. Nat Cell Biol 9: 445-452, 2007

15. Diano S and Horvath TL: Mitochondrial uncoupling protein 2 (UCP2) in glucose and lipid metabolism. Trends Mol Med 18: $52-58,2012$.

16. Sluse FE: Uncoupling proteins: Molecular, functional, regulatory, physiological and pathological aspects. Adv Exp Med Biol 942: 137-156, 2012

17. Cardoso S, Correia S, Carvalho C, Candeias E, Plácido AI, Duarte AI, Seiça RM and Moreira PI: Perspectives on mitochondrial uncoupling proteins-mediated neuroprotection. J Bioenerg Biomembr 47: 119-131, 2015.

18. Chan SH, Wu CA, Wu KL, Ho YH, Chang AY and Chan JY: Transcriptional upregulation of mitochondrial uncoupling protein 2 protects against oxidative stress-associated neurogenic hypertension. Circ Res 105: 886-896, 2009.

19. Arsenijevic D, Onuma H, Pecqueur C, Raimbault S, Manning BS, Miroux B, Couplan E, Alves-Guerra MC, Goubern M, Surwit R, et al: Disruption of the uncoupling protein-2 gene in mice reveals a role in immunity and reactive oxygen species production. Nat Genet 26: 435-439, 2000.

20. Donadelli M, Dando I, Fiorini C and Palmieri M: UCP2, a mitochondrial protein regulated at multiple levels. Cell Mol Life Sci 71: 1171-1190, 2014.
21. Duh EJ, Yang HS, Haller JA, De Juan E, Humayun MS, Gehlbach P, Melia M, Pieramici D, Harlan JB, Campochiaro PA and Zack DJ: Vitreous levels of pigment epithelium-derived factor and vascular endothelial growth factor: Implications for ocular angiogenesis. Am J Ophthalmol 137: 668-674, 2004.

22. Holekamp NM, Bouck N and Volpert O: Pigment epithelium-derived factor is deficient in the vitreous of patients with choroidal neovascularization due to age-related macular degeneration. Am J Ophthalmol 134: 220-227, 2002.

23. Ogata N, Matsuoka M, Imaizumi M, Arichi M and Matsumura M: Decreased levels of pigment epithelium-derived factor in eyes with neuroretinal dystrophic diseases. Am J Ophthalmol 137: 1129-1130, 2004

24. Becerra SP, Dass CR, Yabe T and Crawford SE: Pigment epithelium-derived factor: Chemistry, structure, biology, and applications. J Biomed Biotechnol 2012: 830975, 2012.

25. Karakousis PC, John SK, Behling KC, Surace EM, Smith JE, Hendrickson A, Tang WX, Bennett J and Milam AH: Localization of pigment epithelium derived factor (PEDF) in developing and adult human ocular tissues. Mol Vis 7: 154-163, 2001.

26. Kozulin P, Natoli R, Bumsted O'Brien KM, Madigan MC and Provis JM: The cellular expression of antiangiogenic factors in fetal primate macula. Invest Ophthalmol Vis Sci 51: 4298-4306, 2010.

27. Becerra SP, Fariss RN, Wu YQ, Montuenga LM, Wong P and Pfeffer BA: Pigment epithelium-derived factor in the monkey retinal pigment epithelium and interphotoreceptor matrix: Apical secretion and distribution. Exp Eye Res 78: 223-234, 2004.

28. Perez-Mediavilla LA, Chew C, Campochiaro PA, Nickells RW, Notario V, Zack DJ and Becerra SP: Sequence and expression analysis of bovine pigment epithelium-derived factor. Biochim Biophys Acta 1398: 203-214, 1998.

29. He Y, Leung KW, Ren Y, Pei J, Ge J and Tombran-Tink J: PEDF improves mitochondrial function in RPE cells during oxidative stress. Invest Ophthalmol Vis Sci 55: 6742-6755, 2014.

30. Wankun X, Wenzhen Y, Min Z, Weiyan Z, Huan C, Wei D, Lvzhen $\mathrm{H}, \mathrm{Xu} \mathrm{Y}$ and Xiaoxin L: Protective effect of paeoniflorin against oxidative stress in human retinal pigment epithelium in vitro. Mol Vis 17: 3512-3522, 2011.

31. Tsao YP, Ho TC, Chen SL and Cheng HC: Pigment epithelium-derived factor inhibits oxidative stress-induced cell death by activation of extracellular signal-regulated kinases in cultured retinal pigment epithelial cells. Life Sci 79: 545-550, 2006.

32. Livak KJ and Schmittgen TD: Analysis of relative gene expression data using real-time quantitative PCR a nd the 2(-Delta Delta C(T)) method. Method 25: 402-408, 2001.

33. Yang WQ, Sun DD, Zhao T, Ren DQ and Guo GZ: Effects of erythrocyte relative chemo-luminescence intensities induced by $\mathrm{H}_{2} \mathrm{O}_{2}$ in mice exposed to EMP. Environmental Electromagnetics, the 2006 Asia-Pacific Conference. Proceedings of a meeting held 1-4 August 2006, Dalian, China, pp91-94, 2006.

34. Huang Q, Wang S, Sorenson CM and Sheibani N: PEDF-deficient mice exhibit an enhanced rate of retinal vascular expansion and are more sensitive to hyperoxia-mediated vessel obliteration. Exp Eye Res 87: 226-241, 2008.

35. Wu WC, Hu DN, Gao HX, Chen M, Wang D, Rosen R and McCormick SA: Subtoxic levels hydrogen peroxide-induced production of interleukin- 6 by retinal pigment epithelial cells. Mol Vis 16: 1864-1873, 2010

36. Kaczara P, Sarna T and Burke JM: Dynamics of $\mathrm{H}_{2} \mathrm{O}_{2}$ availability to ARPE-19 cultures in models of oxidative stress. Free Radic Biol Med 48: 1064-1070, 2010.

37. Weigel AL, Handa JT and Hjelmeland LM: Microarray analysis of $\mathrm{H}_{2} \mathrm{O}_{2-}, \mathrm{HNE}-$, or tBH-treated ARPE-19 cells. Free Radic Biol Med 33: 1419-1432, 2002

38. Bailey TA, Kanuga N, Romero IA, Greenwood J, Luthert PJ and Cheetham ME: Oxidative stress affects the junctional integrity of retinal pigment epithelial cells. Invest Ophthalmol Vis Sci 45: 675-684, 2004

39. Hanus J, Anderson C and Wang S: RPE necroptosis in response to oxidative stress and in AMD. Ageing Res Rev 24: 286-298, 2015.

40. Jarrett SG and Boulton ME: Consequences of oxidative stress in age-related macular degeneration. Mol Aspects Med 33: 399-417, 2012.

41. Querques G, Rosenfeld PJ, Cavallero E, Borrelli E, Corvi F, Querques L, Bandello FM and Zarbin MA: Treatment of dry age-related macular degeneration. Ophthalmic Res 52: 107-115, 2014. 
42. Aksenov MY, Aksenova MV, Butterfield DA, Geddes JW and Markesbery WR: Protein oxidation in the brain in Alzheimer's disease. Neuroscience 103: 373-383, 2001.

43. Adams JD Jr, Chang ML and Klaidman L: Parkinson's disease-redox mechanisms. Curr Med Chem 8: 809-814, 2001.

44. Age-Related Eye Disease Study Research Group: A randomized, placebo-controlled, clinical trial of high-dose supplementation with vitamins $\mathrm{C}$ and $\mathrm{E}$, beta carotene and zinc for age-related macular degeneration and vision loss: AREDS report no. 9. Arch Ophthalmol 119: 1439-1452, 2001.

45. Yuan H, Jian G, Burke JM, Myers RL, Dong ZZ and Tombran-Tink J: Mitochondria impairment correlates with increased sensitivity of aging RPE cells to oxidative stress. J Ocul Biol Dis Infor 3: 92-108, 2010.

46. He Y and Tombran-Tink J: Mitochondrial decay and impairment of antioxidant defenses in aging RPE cells. Adv Exp Med Biol 664: 165-183, 2010.

47. Barnstable CJ, Reddy R, Li H and Horvath TL: Mitochondrial uncoupling protein 2 (UCP2) regulates retinal ganglion cell number and survival. J Mol Neurosci 58: 461-469, 2016.

48. Barnstable CJ and Tombran-Tink J: Neuroprotective and antiangiogenic actions of PEDF in the eye: Molecular targets and therapeutic potential. Prog Retin Eye Res 23: 561-577, 2004.

49. Becerra SP: Focus on molecules: Pigment epithelium-derived factor (PEDF). Exp Eye Res 82: 739-740, 2006.

50. Bouck N: PEDF: Anti-angiogenic guardian of ocular function. Trends Mol Med 8: 330-334, 2002.
51. Subramanian P, Locatelli-Hoops S, Kenealey J, Desjardin J, Notari L and Becerra SP: Pigment epithelium-derived factor (PEDF) prevents retinal cell death via PEDF receptor (PEDF-R): Identification of a functional ligand binding site. J Biol Chem 288: 23928-23942, 2013.

52. Geiger RC, Waters CM, Kamp DW and Glucksberg MR: KGF prevents oxygen-mediated damage in ARPE-19 cells. Invest Ophthalmol Vis Sci 46: 3435-3442, 2005.

53. Subramanian P, Mendez EF and Becerra SP: A novel inhibitor of 5-Lipoxygenase (5-LOX) prevents oxidative stress-induced cell death of retinal pigment epithelium (RPE) cells. Invest Ophthalmol Vis Sci 57: 4581-4588, 2016.

54. Yao S, Zhang Y, Wang X, Zhao F, Sun M, Zheng X, Dong H and Guo K: Pigment epithelium-derived factor (PEDF) protects osteoblastic cell line from glucocorticoid-induced apoptosis via PEDF-R. Int J Mol Sci 17: pii: E730, 2016.

55. Ma S, Yao S, Hua T, Jiao P, Yang N, Zhu P and Qin S: Pigment epithelium-derived factor alleviates endothelial injury by inhibiting Wnt/ $\beta$-catenin pathway. Lipids Health Dis 16: 31, 2017.

(i) $(2)$ This work is licensed under a Creative Commons Attribution-NonCommercial-NoDerivatives 4.0 International (CC BY-NC-ND 4.0) License. 